\title{
Health Awareness in the Field of Physical Activity in Slovakia
}

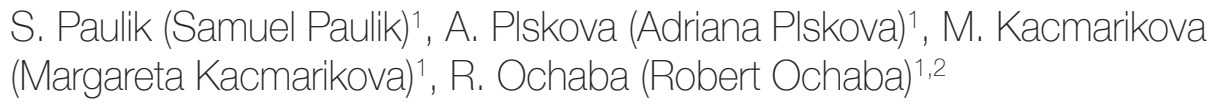

${ }^{1}$ Trnava University, Faculty of Health Sciences and Social Work, Original Article Department of Public Health, SK.

${ }^{2}$ Public Health Authority of the Slovak Republic, Department of Health Promotion and Health Education, Bratislava, SK.

\section{E-mail address:}

samuel.paulik@tvu.sk

\section{Reprint address:}

Department of Public Health

Faculty of Health Sciences and Social Work

Trnava University in Trnava

Univerzitne nam. 1

91843 Trnava

Slovakia

Source: Clinical Social Work and Health Intervention

Volume: 12

Issue: 5

Pages: $8-14$

Cited references: 16

\section{Reviewers:}

Steve Szydlowski

University of Scranton school of education, USA

Pawel S. Czarnecki

Rector of the Warsaw Management University, PL

\section{Keywords:}

Physical Inactivity. Health Awareness. Behavioral Factors. Sedentary Lifestyle.

\section{Publisher:}

International Society of Applied Preventive Medicine i-gap

CSWHI 2021; 12(5): 8 - 14; DOI: 10.22359/cswhi_12_5_01 (C) Clinical Social Work and Health Intervention

\section{Abstract:}

Objectives: The aim of this study was to provide up-to-date information on the prevalence of insufficient physical activity in Slovaks according to gender and age in 2019.

Design: Pilot study

Participants: A cross-sectional survey conducted in 2019 (men $\mathrm{n}=1,298$; women $\mathrm{n}=1,316$ ) monitored 2,614 participants in the age category 15 - 64 years from all over Slovakia. Methods: We statistically analyzed the questionnaire survey on Health Awareness in Slovakia using the Chi-square test and Fisher's test, in which the level of significance was determined p-value $\leq 0.05$. 
Results: Young men preferred active sports compared to young women who preferred to spend time on social networks. Older men preferred light physical activity compared to older women, who preferred reading books and magazines.

Conclusion: With increasing age, the performance of physical activity in Slovaks decreased.

\section{Introduction}

Factors that negatively affect one's vitality are a lack of physical activity and a high level of sedentary behavior during the day (Damen et al., 2020). Physical inactivity is defined as an activity that does not consume sufficient muscle energy (González - Fuentes - Márquez, 2017). Physical inactivity is one of the main risk factors for noncommunicable diseases, ranking 14th in the world and 11th in high-income countries (Leski- nen et al., 2020). A sedentary lifestyle is defined by activities that are performed while sitting or lying down, with energy expenditure equal to or less than 1.5 metabolic equivalents (MET) (Bakker et al., 2020). These activities include the use of electronic devices, reading, writing, drawing, painting, doing homework, sitting at school, on the bus, car, or train (Silva et al., 2020). Sedentary behavior is currently considered a public health problem with high care costs associated

Table 1 Differences in types of physical activity according to gender and age categories (ÚVZ SR 2019)

\begin{tabular}{|c|c|c|c|c|}
\hline Type of physical activity & Age category & Men & Women & p-value \\
\hline \multirow{4}{*}{ Active sport } & $15-18$ years & $38 \%$ & $26 \%$ & \multirow{4}{*}{0,044} \\
\hline & $19-25$ years & $27 \%$ & $27 \%$ & \\
\hline & $26-40$ years & $20 \%$ & $28 \%$ & \\
\hline & $41-64$ years & $15 \%$ & $19 \%$ & \\
\hline \multirow{4}{*}{$\begin{array}{l}\text { Recreational physical } \\
\text { activity } \\
\text { (cycling, dancing) }\end{array}$} & $15-18$ years & $38 \%$ & $39 \%$ & \multirow{4}{*}{0,048} \\
\hline & $19-25$ years & $21 \%$ & $27 \%$ & \\
\hline & $26-40$ years & $15 \%$ & $6 \%$ & \\
\hline & $41-64$ years & $26 \%$ & $28 \%$ & \\
\hline \multirow{4}{*}{$\begin{array}{l}\text { Easy physical activity } \\
\text { (walking) }\end{array}$} & $15-18$ years & $30 \%$ & $27 \%$ & \multirow{4}{*}{0,068} \\
\hline & $19-25$ years & $21 \%$ & $24 \%$ & \\
\hline & $26-40$ years & $31 \%$ & $27 \%$ & \\
\hline & $41-64$ years & $18 \%$ & $22 \%$ & \\
\hline \multirow{4}{*}{$\begin{array}{l}\text { No interest in physical } \\
\text { activity }\end{array}$} & $15-18$ years & $41 \%$ & $36 \%$ & \multirow{4}{*}{0,054} \\
\hline & $19-25$ years & $27 \%$ & $29 \%$ & \\
\hline & $26-40$ years & $28 \%$ & $24 \%$ & \\
\hline & 41-64 years & $5 \%$ & $11 \%$ & \\
\hline
\end{tabular}


with technological progress and industrialization (Cuesta-Vargas et al., 2020).

\section{Methodology}

A cross-sectional survey conducted in 2019 (men $\mathrm{n}=1,298$; women $\mathrm{n}=1,316$ ) monitored 2,614 participants from all over Slovakia. The questionnaire was compiled by the Public Health Authority of the Slovak Republic (ÚVZ SR) focusing on the health awareness of Slovak citizens aged 15 to 64 years. Employees from 36 regional public health offices disseminated the questionnaire in printed form in May and June. The questions focused on basic social and demographic data with regards to the type and frequency of physical activity.

The R-project (version 3.2.2.) was used in the statistical analysis in the form of Chi-square test (frequency $>5$ ) or Fisher's exact test (frequency $<5)$, which were used to determine differences between social, demographic data and frequency of types of physical activity, with p-value $\leq 0.05$ chosen as the level of significance.

\section{Results}

We confirmed statistically significant differences in the type of physical activity. Specifically, we found that boys aged 15 to 18 years (38\%) preferred active sports compared to girls in the same age category $(26 \%)(p=0.044)$. Men in the age category from 26 to 40 years $(15 \%)$ preferred recreational physical activity compared to women in the same age category $(6 \%) \quad(\mathrm{p}=$ 0.048) (Table 1).

Table 2 Differences in daily duration of physical activity according to gender and age categories (ÚVZ SR, 2019)

\begin{tabular}{|c|c|c|c|c|}
\hline $\begin{array}{l}\text { Daily duration of } \\
\text { physical activity }\end{array}$ & Age category & Men & Women & p-value \\
\hline \multirow{4}{*}{ More than 3.5 hours } & $15-18$ years & $31 \%$ & $34 \%$ & \multirow{4}{*}{0,058} \\
\hline & $19-25$ years & $27 \%$ & $32 \%$ & \\
\hline & $26-40$ years & $30 \%$ & $28 \%$ & \\
\hline & 41-64 years & $12 \%$ & $6 \%$ & \\
\hline \multirow{4}{*}{ Approximately 3.5 hours } & $15-18$ years & $35 \%$ & $24 \%$ & \multirow{4}{*}{0,039} \\
\hline & $19-25$ years & $24 \%$ & $35 \%$ & \\
\hline & $26-40$ years & $29 \%$ & $19 \%$ & \\
\hline & 41-64 years & $12 \%$ & $22 \%$ & \\
\hline \multirow{4}{*}{ Less than 3.5 hours } & $15-18$ years & $31 \%$ & $21 \%$ & \multirow{4}{*}{0,028} \\
\hline & $19-25$ years & $27 \%$ & $37 \%$ & \\
\hline & $26-40$ years & $25 \%$ & $29 \%$ & \\
\hline & 41-64 years & $17 \%$ & $13 \%$ & \\
\hline \multirow{4}{*}{ Never } & $15-18$ years & $40 \%$ & $38 \%$ & \multirow{4}{*}{0,064} \\
\hline & $19-25$ years & $27 \%$ & $29 \%$ & \\
\hline & $26-40$ years & $28 \%$ & $27 \%$ & \\
\hline & 41-64 years & $5 \%$ & $6 \%$ & \\
\hline
\end{tabular}


Table 3 Differences in the frequency of performance of individual types of physical activity according to gender and age categories (ÚVZ SR 2019)

\begin{tabular}{|c|c|c|c|c|}
\hline $\begin{array}{l}\text { Frequency of } \\
\text { physical activity } \\
\text { performance }\end{array}$ & Age category & Men & Women & $\mathrm{p}$-value \\
\hline \multirow{4}{*}{$\begin{array}{l}\text { Gardening } \\
1 / 2 / 3 / 4\end{array}$} & $15-18$ years & $87 \% / 6 \% / 3 \% / 4 \%$ & $81 \% / 10 \% / 5 \% / 4 \%$ & 0,061 \\
\hline & $19-25$ years & $2 \% / 16 \% / 50 \% / 32 \%$ & $3 \% / 16 \% / 57 \% / 24 \%$ & 0,051 \\
\hline & $26-40$ years & $13 \% / 30 \% / 24 \% / 33 \%$ & $14 \% / 30 \% / 20 \% / 36 \%$ & 0,068 \\
\hline & 41-64 years & $56 \% / 22 \% / 10 \% / 12 \%$ & $55 \% / 23 \% / 11 \% / 11 \%$ & 0,213 \\
\hline \multirow{4}{*}{$\begin{array}{l}\text { Watching TV, } \\
\text { listening to radio } \\
1 / 2 / 3 / 4\end{array}$} & $15-18$ years & $27 \% / 28 \% / 24 \% / 21 \%$ & $37 \% / 32 \% / 18 \% / 13 \%$ & 0,036 \\
\hline & $19-25$ years & $28 \% / 20 \% / 16 \% / 38 \%$ & $13 \% / 15 \% / 16 \% / 56 \%$ & 0,047 \\
\hline & $26-40$ years & $57 \% / 13 \% / 7 \% / 23 \%$ & $63 \% / 12 \% / 7 \% / 18 \%$ & 0,054 \\
\hline & 41-64 years & $2 \% / 12 \% / 52 \% / 34 \%$ & $1 \% / 13 \% / 55 \% / 31 \%$ & 0,065 \\
\hline \multirow{4}{*}{$\begin{array}{l}\text { Reading } \\
\text { newspapers, } \\
\text { magazines, } \\
\text { books } \\
1 / 2 / 3 / 4\end{array}$} & $15-18$ years & $5 \% / 24 \% / 26 \% / 45 \%$ & $6 \% / 23 \% / 27 \% / 44 \%$ & 0,081 \\
\hline & $19-25$ years & $44 \% / 25 \% / 14 \% / 18 \%$ & $45 \% / 27 \% / 15 \% / 13 \%$ & 0,342 \\
\hline & $26-40$ years & $16 \% / 23 \% / 28 \% / 33 \%$ & $31 \% / 29 \% / 23 \% / 17 \%$ & 0,045 \\
\hline & 41-64 years & $35 \% / 22 \% / 16 \% / 27 \%$ & $27 \% / 20 \% / 18 \% / 35 \%$ & 0,047 \\
\hline \multirow{4}{*}{$\begin{array}{l}\text { Playing Games } \\
\text { on PC, tablets } \\
1 / 2 / 3 / 4\end{array}$} & $15-18$ years & $13 \% / 30 \% / 24 \% / 33 \%$ & $14 \% / 30 \% / 20 \% / 36 \%$ & 0,055 \\
\hline & $19-25$ years & $55 \% / 22 \% / 11 \% / 12 \%$ & $55 \% / 23 \% / 11 \% / 11 \%$ & 0,061 \\
\hline & $26-40$ years & $27 \% / 28 \% / 24 \% / 21 \%$ & $36 \% / 33 \% / 18 \% / 13 \%$ & 0,052 \\
\hline & $41-64$ years & $27 \% / 19 \% / 16 \% / 38 \%$ & $13 \% / 15 \% / 16 \% / 56 \%$ & 0,063 \\
\hline \multirow{4}{*}{$\begin{array}{l}\text { Social networks } \\
\text { (Facebook, } \\
\text { Twitter,...) } \\
\text { 1/ } 2 / 3 / 4\end{array}$} & $15-18$ years & $27 \% / 28 \% / 24 \% / 21 \%$ & $36 \% / 33 \% / 18 \% / 13 \%$ & 0,044 \\
\hline & $19-25$ years & $57 \% / 14 \% / 7 \% / 22 \%$ & $63 \% / 12 \% / 7 \% / 18 \%$ & 0,071 \\
\hline & $26-40$ years & $2 \% / 12 \% / 52 \% / 34 \%$ & $1 \% / 13 \% / 55 \% / 31 \%$ & 0,135 \\
\hline & 41-64 years & $5 \% / 24 \% / 26 \% / 45 \%$ & $6 \% / 23 \% / 27 \% / 44 \%$ & 0,068 \\
\hline \multirow{4}{*}{$\begin{array}{l}\text { Visiting } \\
\text { Cultural events } \\
1 / 2 / 3 / 4\end{array}$} & $15-18$ years & $11 \% / 30 \% / 23 \% / 36 \%$ & $26 \% / 38 \% / 15 \% / 21 \%$ & 0,043 \\
\hline & $19-25$ years & $59 \% / 25 \% / 7 \% / 9 \%$ & $26 \% / 38 \% / 14 \% / 22 \%$ & 0,012 \\
\hline & $26-40$ years & $35 \% / 38 \% / 19 \% / 9 \%$ & $44 \% / 33 \% / 15 \% / 8 \%$ & 0,051 \\
\hline & 41-64 years & $13 \% / 16 \% / 19 \% / 52 \%$ & $9 \% / 12 \% / 12 \% / 67 \%$ & 0,056 \\
\hline
\end{tabular}

${ }^{*} 1 / 2 / 3 / 4$ = every or every other day/1-2-times per week/1-2 times per month/rarely or never 
We found statistically significant differences in daily duration of physical activity. More men in the age group 26-40 years (29\%) performed physical activity daily for approximately 3.5 hours/day compared to women in the same age group (19\%). In contrast, more women in the age group of 41 to 64 years $(22 \%)$ preferred to perform physical activity daily for approximately 3.5 hours/day compared to men in the same age category $(12 \%)(\mathrm{p}=$ $0.039)$. More boys in the $15-18$ age group (31\%) performed less than 3.5 hours/day of physical activity compared to girls in the same age group $(21 \%)(p=0.028)($ Table 2).

We confirmed the differences between the sexes in the frequency of performing individual types of physical activity. Specifically, watching television and listening to radio, where this activity was performed daily by more girls in the 15-18 age group (37\%) compared to boys in the same age group $(27 \%)(\mathrm{p}=0.036)$. On the contrary, more men in the age category 19 to 25 years $(28 \%)$ daily watched TV and listened to radio compared to women in the same age category $(13 \%)(\mathrm{p}=0.047)$. More women in the 2640 age group (31\%) preferred reading books and magazines 1-2 times a week compared to men in the same age group $(16 \%)(\mathrm{p}=0.045)$. In contrast, more men in the 41-64 age group (35\%) preferred reading books and magazines 1-2 times a week compared to women in the same age group $(27 \%)(\mathrm{p}=0.047)$. More girls in the $15-18$ age group preferred spending time on social networks $(36 \%)$ compared to boys in the same age group $(27 \%)(p=0.044)$. More girls in the $15-18$ age group $(26 \%)$ visited cultural events every day compared to boys in the same age group (11\%) ( $\mathrm{p}=0.043$ ). In contrast, more men aged 19 to 25 years $(59 \%)$ visited cultural events compared to women in the same age category $(26 \%)(\mathrm{p}=$ 0.012 ). We did not find statistically significant differences in other types of physical activity (Table 3).

\section{Discussion}

In this study, we confirmed an increasing trend in physical activity with men being more active. The Baltimore Longitudinal Study also found a declining trend in both men and women who spend their time in sedentary behavior; where men also preferred more active sports (Talbot et al., 2003). In a Polish study, they found that approximately $35 \%$ of Polish adults are not physically active in their free time (Drygas et al., 2009). However, the prevalence of a sedentary lifestyle (defined on the basis of low energy expenditure) is high in Europe in adults aged 25-64 years; it ranges from $59 \%$ to $64 \%$ of this age group (Varo et al., 2003). A long-term study in Amsterdam found differences in physical activity between men and women due to different amounts of time spent on mild and intense activities (Karaca et al., 2009).

With a decrease in sedentary behavior, there has been a steady increase in overall physical activity (Sigmund et al., 2009). This increase in intense physical activity has been found in the US population in men only (Talbot et al., 2003). In a Finnish study they also found that physical activity tended to increase with age (Borodulin et $a l ., 2007)$. Due to biological mechanisms a decrease in physical activity is expected with age (Sallis, 2000). This has also been confirmed by adults in the United Kingdom (Miles, 2007). Considering the intensity of the performed physical activity in this study, men are more physically active than women. Similar results were found in the Czech Republic (Suchomel et al., 2008) or in Poland (Drygas et al., 2009).

According to the World Health Organization, physical activity in adults aged 18-64 years includes physical activity in leisure time (walking, dancing, gardening, hiking, swimming), transport (cycling), occupation, housework, games, sports or planned exercise in the context of daily, family and community activities. Physical activity increases muscle fitness, bone health and reduces the risk of non-communicable diseases. Adults aged 18-64 years should perform at least 150 minutes of moderate-intensity aerobic physical activity throughout the week or at least 75 minutes of high-intensity aerobic physical activity throughout the week, or an equivalent combination of medium and high intensity. Aerobic activity should be performed in sessions of at least 10 minutes' duration. For additional health benefits, adults should increase their moderate-intensity aerobic physical activity to 300 minutes per week or engage in 150-minute of high-intensity aerobic physical activity per week, or an equivalent combination of medium- and high-intensity aerobic activity. Muscle strengthening activities should be performed with the participation of large mus- 
cle groups two or more days a week (WHO, 2011).

These recommendations are relevant for all healthy adults aged 18-64 years, unless specific medical conditions indicate otherwise. They apply to all adults, regardless of gender, race, ethnicity or income level. They also apply to individuals with chronic non-infectious conditions, such as hypertension or diabetes and for adults with disabilities. However, certain adjustments may need to be made for each individual based on their physical capacity and specific health risks or limitations (WHO, 2011).

The limitations of the study may be the dishonesty of the participants in the questionnaire survey, for whom it is not possible to prove causal associations between the monitored variables. The positives represent an even distribution of the file according to gender and the undemanding data collection.

Differences in physical activity were demonstrated in the participants, which confirmed the improving movement habits. This study confirmed the strengthening of health awareness in the field of movement habits, but there is still a need to spread information that supports awareness of the benefits of physical activity providing prevention against non-communicable diseases and increasing the overall quality of life.

\section{Conclusion}

With increasing age, the performance of physical activity in Slovaks decreased. Women preferred undemanding physical activity, while men preferred more demanding physical activity. The benefits of physical activity need to be emphasized in national programs to prevent the burden of non-communicable diseases.

\section{Declaration}

The questionnaire in the submitted work was anonymous. At the beginning of the questionnaire respondents received information about the purpose of the questionnaire and its evaluation. The authors have no conflict of interest.

\section{References}

1. BAKKER A et al. (2020) Correlates of Total and domain-specific Sedentary behavior: a cross-sectional study in Dutch adults. In BMC Public Health [online]. Vol. 20, no.
220. P. 230. [cit. 2020-03-11]. Available online:

https://bmcpublichealth.biomedcentral.com/a rticles/10.1186/s12889-020-8316-6.

2. BORODULIN K et al. (2008) Thirty-year trends of physical activity in relation to age, calendar time and birth cohort in Finnish adults. In Eur J Public Health [online]. vol. 18, no. 3, pp. 339-344. [cit. 2020-03-199]. Available online: https://europepmc.org/article/med/17875578.

3. CUESTA-VARGAS A et al. (2020) CrossCultural Adaptation and Psychometric Testing of the International Sedentary Assessment Tool for the Spanish Population. In Int. J. Environ. Res. Public Health [online]. vol. 17, p. 758. [cit. 2020-03-19]. Available online: https://www.ncbi.nlm.nih.gov/pmc/articles/PMC7037491/.

4. DAMEN E et al. (2020) A Scoping Review of Digital Tools to Reduce Sedentary Behavior or Increase Physical Activity in Knowledge Workers. In Int. J. Environ. Res. Public Health [online]. vol. 17, no. 2, p. 499. [cit. 2020-02-17]. Available online: https:// pubmed.ncbi.nlm.nih.gov/31941096/.

5. DRYGAS W et al (2009) Epidemiology of physical inactivity in Poland: Prevalence and determinants in a former Communist country in socioeconomic transition. In Public Health [online]. no. 123, pp. 592-597. [cit. 2020-0318]. Available online: https://europepmc.org/ article/med/19740497.

6. GONZALEZ K, FUENTES J, MARQUEZ J L (2017) Physical Inactivity, Sedentary Behavior and Chronic Diseases. Korean J Fam Med., 2017, vol. 38, no. 3, pp.111-115. doi: 10.4082/kjfm.2017.38.3.111.

7. KARACA A (et al.) (2009) Physical activity levels of the young adults in an economically developing country: The Turkish sample. In J. Hum Kinet [online]. vol. 22, pp. 91-98. [cit. 2020-02-18]. Available online: https:// content.sciendo.com/view/journals/hukin/22/ 2009/article-p91.$x m l$ ?product $=$ sciendo.

8. LESKINEN T et al. (2020) Comparison between recent and long-term physical activity levels as predictors of cardiometabolic risk: a cohort study. In $B M J$ [online]. vol. 10, p. 15 [cit. 2020-03-19]. Available online: https:// bmjopen.bmj.com/content/10/2/e033797. 
9. MILES L (2000) Physical activity and health. In Nutrition Bulletin. [online]. vol. 32, pp. 314-363. [cit. 2020-03-17]. Available online: https://onlinelibrary.wiley.com/doi/full/10.11 11/j.1467-3010.2007.00668.x.

10. SALLIS J F (2000) Age-related decline in physical activity: a synthesis of human and animal studies. In Med Sci Sports Exerc. [online]. vol. 32, no. 9, pp. 1598-1600. [cit. 2020-03-13]. Available online: https://pubmed.ncbi.nlm.nih.gov/10994911/.

11. SIGMUND E et al. (2009) Variability of selected indicators of physical activity in a randomized sample of the Czech population between the years 2003-2006: Results from the short and long self-administered format of the IPAQ questionnaire. In Acta Univ Palacki Olomuc Gymn. [online] vol. 39, no. 2, pp. 23-31. [cit. 2020-02-14]. Available online: https://gymnica.upol.cz/artkey/gym-2009020003_Variability_of_selected_indicators_of_ physical_activity_in_a_randomized_sample_of_the_Czech_population_between_.ph.

12. SILVA $M$ et al (2020) National Adolescent School-based Health Survey - PeNSE 2015: Sedentary behavior and its correlates. In PLoS One [online]. vol. 15, no. 1, pp. 89 - 96 [cit. 2020-03-16]. Available online: https://journals.plos.org/plosone/article?id=1 0.1371/journal.pone. 0228373 .

13. SUCHOMEL M et al. (2011) Gender Differences in Physical Activity, Sedentary Behavior and BMI in the Liberec Region: the IPAQ Study in 2020-2009. In Journal of Human Kinetics [online]. vol. 28, pp. 123-131; doi: 10.2478/v10078-011-0029-6. [cit. 2020-0317]. Available online: https://www.ncbi.nlm. nih.gov/pmc/articles/PMC3592106/.

14. TALBOT L A et al. (2003) Secular trends in leisure-time physical activity in men and women across four decades. In Prev Med. [online]. vol. 37, pp. 52-60. [cit. 2020-0311]. Available online: https://www.sciencedirect.com/science/article/pii/S0091743503000 586.

15. VARO J J et al. (2003) Distribution and determinants of sedentary lifestyle in the European Union. International Journal of Epidemiology. [online]. vol. 32, pp. 138-146. [cit. 2020-0215]. Available online: https:// academic.oup. com/ije/article/32/1/138/642829.
16. WORLD HEALTH ORGANIZATION (WHO) (2011) Physical Activity and Adults. [online]. 2011. [cit. 2020-03-17]. Available online: https://www.who.int/dietphysicalactivity/factsheet_adults/en/. 